\section{Life Cycle Assessment of Different Low-Temperature District Heating Development Scenarios: A Case Study of Municipality in Latvia}

\author{
Maksims FEOFILOVS ${ }^{1 *}$, Ieva PAKERE ${ }^{2}$, Francesco ROMAGNOLI $^{3}$ \\ ${ }^{1-3}$ Institute of Energy Systems and Environment, Riga Technical University, \\ Azenes iela 12/1, Riga, LV-1048, Latvia
}

\begin{abstract}
Sustainable heating solutions involving renewable energy sources and low supply/return temperatures for district heating are evolving. Low temperature use in district heating allows reducing the heating operation costs significantly and at the same time holding the sustainability criteria. However, an in-depth study on environmental impacts during the life cycle of low temperature district heating was not conducted until now. Thus, this study aims to find the best development scenarios for development of local low temperature district heating. For this purpose, a methodology adopts life cycle analysis approach that allows assessing the environmental impacts according to a variety of environmental performance criterions. The results of the study showed an improvement in the overall environmental performance towards the transition of a conventional $3^{\text {rd }}$ generation district heating to low temperature concept including the effects of reconstruction and modernization of the boiler house. A set of potential development is proposed. Specifically, the scenario implementing low temperature district heating with solar PV showed the best score for environmental performance. The scenario with implementation of low temperature district heating without solar PV did not show significant improvement in environmental performance under operation conditions of a pilot case study.
\end{abstract}

Keywords - District heating modernization; environmental impact; Life Cycle Assessment (LCA); Low Temperature District Heating (LTDH); Solar Photovoltaics (PV)

\begin{tabular}{lll}
\hline \multicolumn{2}{c}{ Nomenclature } & \\
$\pi$ & The ratio of the circumference of a circle to its diameter & \\
$\rho$ & Density of pipeline material & $\mathrm{kg} / \mathrm{m}^{3}$ \\
$\eta$ & Boiler efficiency for fuel frequency factor & $\%$ \\
$B_{i}$ & Fuel consumption for fuel $i$ & tonnes per year \\
$l$ & Length of pipeline & $\mathrm{m}$ \\
$Q_{i}$ & Produced heat & $\mathrm{MWh}$ per year \\
$Q^{z}{ }_{d}$ & Lowest calorific value for fuel $i$ & $\mathrm{MWh} /$ tonnes per year \\
$R_{n}$ & outer radius of pipeline material $n$ & $\mathrm{~m}$ \\
$r_{n}$ & inner radius of pipeline material $n$ & $\mathrm{~m}$ \\
$V_{n}$ & volume of pipeline material $n$ & $\mathrm{~m}^{3}$ \\
\hline
\end{tabular}

${ }^{*}$ Corresponding author.

E-mail address: maksims.feofilovs@rtu.lv 


\section{District Heating in The Context OF Sustainability}

Sustainable heating solutions have evolved over the last decades at European level [1]. Such solutions require increase of the utilization of renewable energy sources (RES) for district heating $(\mathrm{DH})$ purposes [2]-[5], that will contribute to reductions in fossil energy use [4] and to decrease environmental impacts of $\mathrm{DH}$ by cutting $\mathrm{CO}_{2}$ emissions [5]. According to Connolly et al. [6] estimates on DH and renewable heat potentials in European Union member states for 2030 and 2050, heating and cooling costs can be reduced by $15 \%$, which equals to approximately EUR 100 billion per year. Besides increasing utilization of RES another important challenge for sustainable heating is making use of low temperatures in $\mathrm{DH}$.

The importance of low temperature district heating (LTDH) systems in future smart energy systems was highlighted by Lund et al. [2], by summarizing that low temperature DH systems can lower energy losses, utilize industrial excess heat, balance the renewable energy in the electricity grid and have strong economic potential if properly implemented. Some of Lunds' statements can be confirmed with results of other studies, for example, a case study on DH of Helsinki, which investigated the effects of potential benefit of low temperatures in distribution network of DH powered by combined heat and power (CHP) together with solar collector, boilers and heat pumps, found that the change of supply temperature from range of $80{ }^{\circ} \mathrm{C}$ to $110^{\circ} \mathrm{C}$ to a constant supply temperature of $65^{\circ} \mathrm{C}$ improves system performance in terms of cost and emission reductions by $4 \%$ [7]. A foretime estimations on low temperature district heating (LTDH) showed possible reduction of heat loss by $75 \%$ comparing with medium temperature DH system [8]. Imran et al. [9] in addition to heat losses mentioned other possible benefits like reduction of boiling risk, reduced thermal stress on materials along the pipeline, utilization of thermal storage to handle peak loads without oversizing equipment, improving heat to steam ratio in steam CHP system to extract more power of the turbine.

According to Imran et al. [9], for the implementation of low supply and return temperatures, customer substations and secondary heating systems must perform without temperature faults and continuous commissioning is necessary to detect temperature faults without delays. Also, thermal storages have an important role for improvement of flexibility of DH system [10]. With the help of the latest automatic metering systems fault detection has changed from being slow and expensive to becoming fast and inexpensive and thus more efficient DH systems with low supply and return temperatures can be put into practice [11]. Such systems match general sustainability criterions as they bring positive environmental and economic net gains. However, the interpretation of such criterions can differ depending on the needs of policy planning and decision making. Therefore, in this study the existing methods for sustainability and environmental impact assessment of DH are reviewed to substantiate the need for Life Cycle Assessment (LCA) on a pilot case study of DH to find the best solutions for development of LTDH from the environmental performance perspective.

\section{DiSTRICT HEATING ENVIRONMENTAL IMPACT METRICS}

\subsection{Sustainability and Environmental Impact Assessment of DH}

Among all the available methods to determine the environmental impacts in the energy sector most used is Global Warming Potential (GWP) enhancing Climate Change in terms of $\mathrm{CO}_{2}$ equivalent of all Green House Gases (GHG) [12], [13]. However, referring only to GWP reduction as the only sustainability criteria to be assessed it could be misleading because other environmental impacts can play a relevant role on the assessment of the environmental profile 
of the DH operational system and because carbon dioxide emissions only partly are addressed to the climate change. For cases when biomass is addressed as carbon neutral without considering variation of carbon stock over time [14] other pollutants like $\mathrm{SO}_{\mathrm{x}}, \mathrm{NO}_{\mathrm{x}}$ and particulate matters would give deeper insight about the overall environmental performance of the system [15], [16] not directly linked to the GWP.

Caputo et al. [17] in his study in addition to the emissions from DH used primary fossil fuel energy savings as an indicator to determine the environmental performance of DH in different scenarios and in this way included in his assessment the impact of DH system on resource depletion. Similar to savings of primary fossil fuel energy, the exergy method is used to determine more efficient ways of energy resource use [18]. The exergy concept meets environmental constraints in terms of irreversibility or lost work due to the system performance [19]. In this direction the work of Baldvinsson et al. [20] presents a case study on DH with biomass CHP in North Japan with high exergy efficiency of low temperature operation in DH due to high quality of electricity, because lower network temperature helps to achieve lower primary energy consumption and higher electricity generation in a CHP plant. Similarly, this concept was also underlined by [9].

Yazici [21] after studying geothermal DH found that lower network temperature overall provides least primary energy consumption due to higher electricity generation of CHP plant and exergy losses occur mainly because of the heat carrier, the heat exchanger losses, the losses of all pumps and pipeline loses as $15.94 \%, 12.44 \%, 5.52 \%$ and $5.52 \%$ of the total exergy input to the system. However, these are only the internal indicators of a system, which do not show the external effects linked to specific pilot case conditions, for example of marginal electricity mix that can affect environmental and sustainability performance of the studied system.

Laukkanen et al. [22] in this study used Primary Exergy Analysis (PeXa) method, which combines Primary Energy Efficiency and Exergy Analysis. The main difference from exergy analysis is that PeXa considers the system exergetic values of the products, while exergy considers only the products produced in the studied process, thus PeXa addresses also the external effects. Laukkanen et. al. also suggested that PeXa method should be developed further to assess multi-product processes and with other factor calculation like $\mathrm{CO}_{2}$ emissions can also be used to analyse the life cycle of a processor product by including the total production system into model. Kouhia et al. [14] proceeded in that direction by studying PeXa factor with variance of parameters that influence $\mathrm{DH}$ design, minimum $\mathrm{CO}_{2}$ emissions, including maximum profit and minimum exergy losses. The study suggested considering metrics for sustainability that can include more externalities.

Andric et al. [23] introduced the concept of externalities using an emergy approach to assess three different DH network types with three different heat production options:

1) DH with central boiler running on different fuels (biofuels, petroleum, light fuel oil, landfill gas);

2) Central solar plant with thermal storage;

3) Natural gas boilers.

For all the systems tested, the operation phase was found to be the main contributor to total environmental impact and therefore including the RES into DH would help to decrease these impacts. Even though the emergy approach addresses construction of a system and use phase of products, which are the same steps as in LCA approach, the background of emergy can be dubious. The basic idea behind emergy approach is that product or service is more sustainable when more energy is available for further transformations of this product or service. Hence, the emergy is defined as the available energy of one form that is used up in transformations 
directly and indirectly to make a product or a service. Emergy gives a measure to the work of the environment that would be needed to replace what is consumed in different phases of a system's life cycle [24].

Coss et al. [25] stated that policy strategies that focus only on one criteria, like environmental or economic targets only, do not seem useful for a sustainable energy system design, because the multi-dimensional nature of sustainability is not taken into account, and proposed a holistic design approach including the emergy approach for environmental performance assessment in a multi-objective performance assessment together with levelized costs of providing energy by heating plant for economic and total system efficiency for technological assessment. After applying this methodology to a case study, he concluded that the link between minimizing emergy and maximizing equipment efficiency does not always hold true, specifically when different fuels and loads of equipment are considered. This showed that emergy approach does not always provide best solution from energy efficiency point of view and thus should be used together with other relevant criteria for energy efficiency. At the same time, the drawback of using emergy approach as standalone criteria is that it is too much holistic from environmental point of view. The effects of human activities on natural systems are assessed in common "emergy units" [26] and there is no insight on specific impacts on ecosystem quality and humans health.

In this context, LCA can give more insight to decision making of DH modernization for more sustainable pathways by assessing many environmental impacts. None of the methods reviewed above can give such extensive information on environmental impacts as LCA. Thus, for the purpose of this study LCA approach is suggested and described in the methodology part of this study.

\subsection{LCA of District Heating}

For the purpose of this study existing LCA studies on DH infrastructure were reviewed to obtain the understanding of the current state-of-art of LCA on DH. A summary of studies found in literature over a period of the last ten years is presented in Table 1 for comparison.

TABle 1. SELECTION OF STUdies PERFORMING LCA OF DH

\begin{tabular}{|c|c|c|c|}
\hline Author, year of study & Methodology & Subject of study & Software \\
\hline Oliver-Sola, 2009 [27] & $\begin{array}{l}\text { LCA ISO } 14041 \\
\text { and } 14042\end{array}$ & $\begin{array}{l}\text { DH infrastructure with street section of } 100 \mathrm{~m}, 10 \\
\text { blocks of } 24 \text { dwellings each }\end{array}$ & Gabi 4 \\
\hline Nitkiewicz, 2014 [28] & LCA ISO 14040 & $\begin{array}{l}\text { Low-temperature heating plant with electric heat } \\
\text { pump, absorption heat pump and gas-fired boiler }\end{array}$ & SimaPro 7.3 .2 \\
\hline Parajuli, 2014 [29] & LCA & District heat production in a straw fired CHP plant & SimaPro 7.3 .3 \\
\hline Ivner, 2015 [30] & LCA ISO 14040 & Industrial excess heat in DH system & $\begin{array}{l}\text { SimaPro software } \\
\text { and ENPAC tool }\end{array}$ \\
\hline Sandvall, 2017 [31] & TIMES & $\begin{array}{l}\text { Small-town, medium-sized and a large DH system } \\
\text { with specific characteristics in terms of DH supply } \\
\text { technologies and fuel use }\end{array}$ & TIMES_UH model \\
\hline Bartolozzi, 2017 [32] & $\begin{array}{l}\text { LCA ISO } 14040 \\
\text { and } 14044\end{array}$ & $\begin{array}{l}\text { Heating and cooling in residential neighbourhood of } \\
1000 \text { inhabitants (equivalent to } 250 \text { apartments), } \\
\text { located in Tuscany, Italy }\end{array}$ & SimaPro 8.02 \\
\hline Havukainen, 2018 [33] & $\begin{array}{l}\text { LCA ISO } 14040 \\
\text { and } 14044\end{array}$ & $\begin{array}{l}\text { Small-scale CHP plant fired by forest biomass, } \\
\text { located in the Saimaanharju, Taipalsaari, Finland }\end{array}$ & GaBi 6.0 \\
\hline Pericault, 2018 [34] & LCA and cost & $\begin{array}{l}\text { System processes of five alternatives for water } \\
\text { supply, sanitation and heating in a residential area in } \\
\text { Gallivare, Sweden }\end{array}$ & Open LCA \\
\hline
\end{tabular}


The studies presented in Table 1 are made as case studies of a specific DH case or as comparative studies about application of different technologies. The methodologies for LCA differ across the presented studies, but the most common methodology remains LCA ISO standard. Latest studies employ LCA ISO standards 14040 and 14044. Two of the studies found have different methodologies: one applies TIMES method for $\mathrm{CO}_{2}$ emission calculation with TIMES_UH model, another implements LCA and cost assessment with Open LCA software. The most popular software among reviewed studies is SimaPro.

One of the earliest studies found is by Oliver-Sola et al. [27], in which LCA was performed on DH systems. The study determined environmental impacts of a $\mathrm{DH}$ infrastructure in an urban neighbourhood. The objective of study was to identify which subsystems and components of a DH grid are the main contributors to the overall impact on environment. The analysis of the study covered seven subsystems: power plant; main grid; auxiliary components of the main grid; trench works, service pipes, buildings and components of dwellings. Data was gathered from Ecoinvent 1.2 and PE Europe database. The data for components was averaged from based on a real DH network. The study applied CML 2 Baseline 2000 for the following impact categories: acidification potential (AP), eutrophication potential (EP), global warming potential (GWP), human toxicity (HTP), ozone layer depletion (ODP), abiotic depletion (ADP). The functional unit for this study was chosen as neighbourhood infrastructure that serves to provide heat for satisfying the domestic requirements for space heating and sanitary hot water of standard family in 240 dwellings within a local urban neighbourhood for 50 years. The study did not include the energy consumption or heat losses during use phase and for transportation only local resource transportation was included. Results of the study showed that neighbourhood system that is the main contributor in four impact categories $(49.4 \%$ in EP, $59.5 \%$ in GWP, $65.1 \%$ in ODP, $44.8 \%$ in ADP), while building system was a less relevant contribution. The study made an important conclusion that strategies for environmental impact reduction should be checked for problem-shifting between life-cycle phases and all parts of DH systems, and for this purpose, the LCA method is an appropriate tool. More studies since the work of OliverSola et al. performed LCA of DH that are different in scope and scale. This difference in scope and scale showed important findings of further work in LCA on DH. Most findings address the application energy sources during the use phase of DH system.

Nitkiewicz et al. [28] in the study on low temperature heat plant using an electric heat pump, absorption heat pump and a gas-fired boiler considered the seasonality of heat production and electricity generation reduction in CHP considering its efficiency and substituted marginal electricity mix. In the analysed scenario the characteristic temperature of DH network was $50 / 40^{\circ} \mathrm{C}$. Study boundaries included facility construction, fuel extraction, processing and transport, electricity generation and distribution for facility operation and facility operation itself. However, the study did not include information about DH network grid. Functional unit was chosen as the heating plant system with given amount of heat to be delivered to meet local heat demand in assumed average season. The study evaluated life cycle impact with eco-indicator ' 99 in three damage categories: damage to human health, damage to ecosystem quality, damage to resources. Study concluded that electrical heat pump with low efficiency can have higher environmental impact than gas boiler in DH system.

A study of Ivner et al. [30] applied GWP100 method to evaluate effect of the use of industrial excess heat in DH on GHG in future energy markets. Functional unit of $1 \mathrm{GJ}$ heat delivered was used for this purpose. Study boundaries included Resource extraction, fuel refining, fuel inputs and facility operation, electricity and heat distribution. Data was obtained from Ecoinvent database and Swedish Environmental Research institute for average 
estimations for heat production in Sweden, while ignoring the production losses. Study found that industrial excess heat utilization through DH can be beneficial in some conditions and suggested that EU-policy should recommend use of biomass for emission reduction.

Parajuli et al. [29] performed LCA of DH production in a straw fired CHP by using "Stepwise2006" lice cycle assessment method with functional unit of $1 \mathrm{MJ}$ of heat production to determine if straw for production of a CHP plant is better than in DH from a boiler. Study boundaries included the straw removal process, collection and pre-processing, conversion to heat and power, substitution of marginal electricity. Study found that use of straw for substitution of marginal electricity has lower environmental impact compared to natural gas in GWP and NRE-use, but leads to higher AP, EPs.

For cradle-to-grave type LCA Bartolozzi et al. [32] applied the ILCD 2011 Midpoint method to evaluate the thermal energy supply for heating, sanitary hot water and cooling of residential buildings in $\mathrm{DH}$ with biomass energy and shallow geothermal energy scenarios in lifetime of 50 years. For smaller parts of DH, such as flow limiting devices and heat meters, lifetime of 15 years was considered. These scenarios were benchmarked according to centralized and decentralized natural gas use for heating and cooling scenarios. Functional unit of performance of system in terms of energy units per year was applied. Study found that transportation of resources does not make significant contribution because of short transport distances. Results confirmed that DH with combined with RES can improve carbon footprint and resource depletion of energy production system. Thus, the study suggested to use RES in form of biomass and shallow geothermal energy to decrease the impacts.

Havukainen et al. [33] in the study about different forest biofuel use and replacement of natural gas in small-scale combined heat and power plant used CML2001 assessment method with impact categories of GWP, AP and EP. The functional unit of $1 \mathrm{MJ}$ of produced energy was used. Study concluded that when using forest biomass instead of natural gas in energy production, the global climate impacts are reduced (excluding biogenic carbon), but the local effects like AD and EP are higher. When biogenic carbon is considered in assessment the calculated climate benefit in terms of total emissions end up to reach 4-7\% over that of natural gas use because of the environmental impacts during their production, especially for pellets due to amount of electricity and heat required for their production. However, study did not consider the transportation of gas from the extraction field.

The latest study of Pericault et al. [34] addressed LTDH in one alternative of 5 alternative scenarios for combination of sewerage, freeze protection and heating solution in LCA type of study on heat production, drinking water production and sewage water treatment, transport to and from the residential area and transport within the residential area. The scenarios where compered by sustainability criteria in five categories: environmental, economy, social, health and safety, and technical. For environmental assessment the energy efficiency in terms of climate preservation in terms of GWP, material efficiency in terms of abiotic depletion potential of elements (ADPE). Study boundaries included processes related to the production, transport, construction, maintenance and use phase of the elements. Also, sensitivity analysis of criteria weights was performed. The analysis showed that economic factor of affordability is the most sensitive criterion that can influence the results of assessment, followed by material efficiency criterion, which was chosen as one of environmental criterions and had relatively low weight compared to other indicators. Climate preservation also has a relatively low weight, but did not influence the results. In conclusion, the study suggested to make integration of LTDH with sewer and water pipes in one trench from perspective of costs. Such approach would also score the highest for sustainability if DH source would be changed from biomass to shallow geothermal energy. The data for this study was gathered from European 
Life Cycle Database and Oekobaudat databases, environmental product declarations, scientific publications and personal communications with companies.

Summarizing the reviewed studies, the main aspect for applying LCA is the comprehensive scope that this methodology can capture for system performance assessment. These studies help to determine which aspects are crucial to consider in further work and gaps that are yet to be filled. Based on this information the current study further will aim to find optimal solutions for LCA case study on existing LTDH development pilot project.

\subsection{Case Study of LTDH}

Considering the interpretation and findings from LCA studies on DH shown (Table 1), this study further adopts the methodology for a pilot case study of LTDH located in the eastern part of Latvia, namely in the Belava parish located in the municipality of Gulbene [35]. In pilot case, reconstruction of existing heating network was performed. In former $\mathrm{DH}$, heat was produced in a boiler house from firewood, which according to Sneum et al. [36] is one of the more competitive way of producing heat than electric boilers in context of the Baltic states.

For the particular pilot, the DH network has been optimized in order to increase the overall heat density and system efficiency. Before the reconstruction (existing heating network in Fig. 1) in total nine buildings were connected to DH with total heating area of $4467 \mathrm{~m}^{2}$. After the reconstruction, only five buildings (total $4067 \mathrm{~m}^{2}$ ) are connected to DH system from which thee buildings are renovated. Therefore, it is assumed that the installed heating surfaces in the building would be sufficient to provide necessary indoor climate conditions with lower heat supply temperature. For optimal design and modernization of $\mathrm{DH}$, the reconstruction of old DH includes reduction of DH pipeline length from $917 \mathrm{~m}$ to $491 \mathrm{~m}$, change of DH node components such as valves and pumps, change of pipelines, boiler house, fire wood boiler and its components to pellet boiler, and thus increase of heat production efficiency. The realized pilot is reported in Fig. 1 and in detailed described in the section 3.2.

For insulation of pipelines in old DH stone wool is used, while in new DH pipelines polyurethane foam insulation from industrial production are used. New boiler house is set in modular container and heat is produced in wood pellet boiler with automatic silo and storage area. The old boilerhouse did not have a storage area or silo and heat was produced in a firewood boiler.

The design of pilot project for LTDH development considers that there will be efficiency gains from reconstruction of heating network, change of boiler and the reduction of supply and return water temperature from $90 / 60{ }^{\circ} \mathrm{C}$ to $60 / 35^{\circ} \mathrm{C}$. This corresponds to suggestion found in study of Park et al. [37] to have temperature of $60 / 35^{\circ} \mathrm{C}$ in order to avoid significant increase in pumping power and domestic hot water heat exchanger costs. For supply and return temperature decrease, findings in literature suggest that direct effects include changes in heat loss, pumping power, and domestic hot water heat exchanger operation costs. 


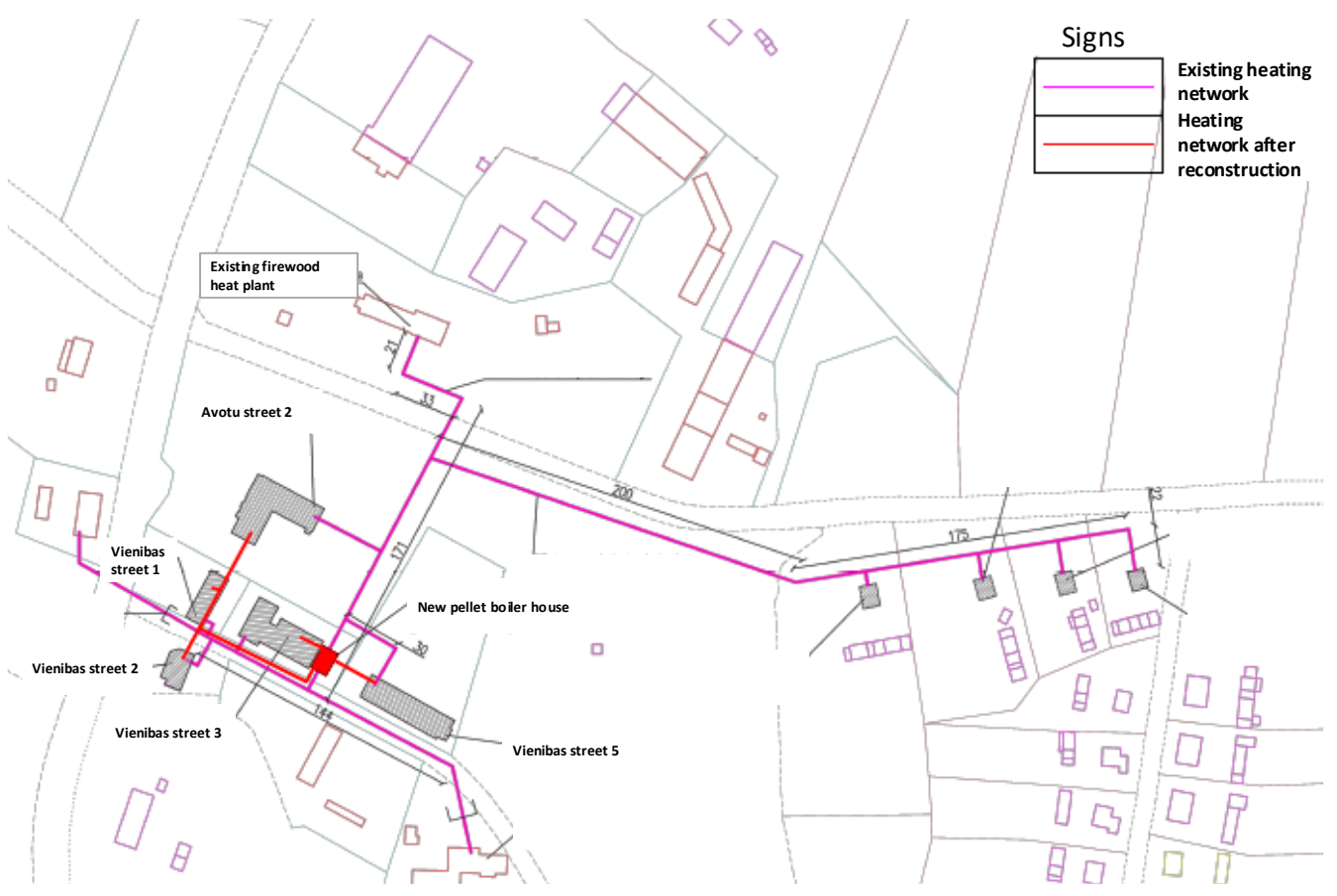

Fig. 1. Analysed DH network before and after reconstruction [35].

The change in power consumption for pumping due to temperature decrease in DH can differ depending on system. Flores et al. [38] in a study on load impacts of LTDH connected to conventional DH network for case of Stockholm, Sweden, found that the impact of LTDH with operating conditions $55.2 / 30.1{ }^{\circ} \mathrm{C}$ in convention DH network with operating conditions $81.7 / 46.3{ }^{\circ} \mathrm{C}$ decrease relative pumping power. Another case study on DH in Sweden found that decrease of temperature from $80 / 40{ }^{\circ} \mathrm{C}$ to $65 / 30{ }^{\circ} \mathrm{C}$ and $50 / 20{ }^{\circ} \mathrm{C}$ increase the electricity consumption for pumps in DH in the case of reduced supply and return temperature. According to Kauko et al. [39], such increase of electricity demand for recirculation flow due to decrease of temperatures in DH will be very low. Moreover, in case study the difference between supply and return temperatures did not change, thus the study considers that the electricity consumption for pumps will not change.

Findings in literature [40] suggest increasing the RES utilization in the electric power mix, because DH supply and return temperature reduction can lead to higher $\mathrm{CO}_{2}$ emissions, in cases when electricity demand is increased. Regarding this aspect, during the pilot case project development, additional application solar PV was considered. Solar PV application in $\mathrm{DH}$ ensures both the replacement of fossil fuel and a decrease in $\mathrm{CO}_{2}$ emissions [41], thus the study includes solar PV implementation scenario in life cycle assessment.

\section{Methodology}

This particular case study aims to implement LCA methodology to provide an assessment on environmental impacts of different renewing/modernizing scenarios of an existing DH system to a LTDH system, which also includes the application of solar PV. The development 
of the LCA mainly follows the ISO 14044 standard, which identifies four phases of LCA studies:

1) Goal and scope definition phase;

2) Inventory analysis phase;

3) Impact assessment phase;

4) Interpretation phase.

First three phases for this study are described further in 3.1., 3.2. and 3.3. parts of methodology. The interpretation phase is included as the analysis of results, and discussion and conclusions part of this paper.

\subsection{Goal and Scope}

The goal of this study is to assess environmental impacts of different renewing/modernizing scenarios of an existing DH system to a LTDH system, which also includes the option for application of solar PV. For the comparison of the new DH operation also the DH model before the renovation is included as one of the studied scenarios as business-as-usual scenario. Since the former DH system included more residential house connections than new one, the Functional unit thus includes the relation to the heated area in order to compare the performance of renovation scenario. The selected Functional unit is the construction of DH and produced energy over assumed lifetime of $\mathrm{DH}$ per heated area. The study in total includes four scenarios for one DH located in municipality in the eastern part of Latvia, namely, in parish of Belava of Gulbene Municipality:

- Scenario 1: New LTDH with supply and return temperatures $60 / 35^{\circ} \mathrm{C}$;

- Scenario 2: New LTDH with supply and return temperatures $60 / 35^{\circ} \mathrm{C}$ and solar PV;

- Scenario 3: New DH with supply and return temperatures $90 / 60{ }^{\circ} \mathrm{C}$;

- Scenario 4: Former DH with supply and return temperatures $90 / 60{ }^{\circ} \mathrm{C}$.

The Life cycle inventory (LCI) of the proposed LCA is defined considering the information found in literature about LCA on DH and the availability of information for this specific case study. The study boundaries include the assembly stage of DH and its components, the operation phase with heat production, electricity consumption and maintenance of $\mathrm{DH}$ in terms of replacement of taps, valves, pumps and surface boxes over the 20-year lifetime. The study considered new LTDH and DH scenario comparison in respect to the former DH (also including impact for construction, operation and maintenance). The disposal phase is not included in the study, except the waste treatment already considered in products from Ecoinvent 3 database. Also, additional transportation of products was not considered, except the transportation that is already defined by default in Ecoinvent 3 database. All of the scenarios include the following parts of DH system: boiler house, pipelines, DH pipeline nodes. In addition to other parts, scenario 2 also includes a solar PV plant for powering the boiler house and pumps. All scenarios consider electricity connection to the grid.

\subsection{Life Cycle Inventory}

To create a model of DH infrastructure for LCA the information about DH modernization was obtained directly from the municipality, including the data for every assembly specified in inventory of pilot $\mathrm{DH}$, such as valves, pumps, pipelines, insulation, heat meters, wells, ventilation system and excavation works, etc. Data for these assemblies were obtained from certificates of manufacturers and compared to available materials and processes in the Ecoinvent 3 database. Assemblies of $\mathrm{DH}$ that have an equivalent object in the Ecoinvent 3 database were selected from the database. For assemblies that do not have an equivalent object 
in the Ecoinvent 3 database, the amount of materials and processes needed for production of the particular assembly has been selected from the Ecoinvent 3 database.

The number of accounted assemblies in inventory of pilot $\mathrm{DH}$ are listed in Table 2 . This table also shows how many assemblies were found in Ecoinvent 3 based on their similarity to the assemblies from pilot DH inventory and how many similar assemblies were not found in the Ecoinvent 3 database, hence, were included in LCA in terms of material flow and processes or excluded from the model used in impact assessment. The example of DH infrastructure LCI data for scenario 2 is shown in Annex. Data for energy flows is added to scenario separately from infrastructure data.

TABLE 2. ENERGY Flows IN DEFINED SCENARIOS

\begin{tabular}{lllll}
\hline Part of DH & $\begin{array}{l}\text { Assemblies } \\
\text { accounted }\end{array}$ & $\begin{array}{l}\text { Assemblies from } \\
\text { Ecoinvent 3 database }\end{array}$ & $\begin{array}{l}\text { Assemblies accounted in terms } \\
\text { material flow and processes }\end{array}$ & $\begin{array}{l}\text { Assemblies } \\
\text { excluded from LCA }\end{array}$ \\
\hline Boiler house & 97 & 13 & 67 & 17 \\
Pipelines & 94 & 10 & 76 & 8 \\
DH nodes & 189 & 5 & 150 & 44 \\
Solar PV & 9 & 6 & 2 & 1 \\
\hline
\end{tabular}

Following assemblies and processes with potentially low impact over DH lifetime were excluded: alcoholic thermometers, pressure gauge, warning tapes, labelling of heating unit, fasteners, wall brackets, anti-corrosion reagent, pipeline fittings, DH system testing, adjustment and startup, chimney installation. For pipeline network modernization compensating pillows, renovation of asphalt pavement and replacement of soil were excluded. In terms of the solar PV system delivery, adjustment and startup process was excluded from the model.

As suggested by [28], the lifetime for DH boiler house, pipelines and trench works was defined as 20 years; for surface boxes, flow limiting devices, heat meters and heat exchangers the lifetime was as 15 years and for pumps and taps - 10 years, because of material uncertainties and lack of reliable data on lifespan of components.

Inventory for scenarios with new DH for optimal design and modernization includes the reconstruction of old $\mathrm{DH}$ by disabling four consumers from $\mathrm{DH}$ network in order to increase heat density in network and thus reducing DH pipeline network length from $917 \mathrm{~m}$ to $491 \mathrm{~m}$, change of DH node components and pipelines, change of boilerhouse, including furnace and other its components, and thus change in boiler heat production efficiency and reduction of power consumption for pumps. For insulation of pipelines in former DH pipelines stone wool was used, while in the new DH pipelines polyurethane foam insulation from industrial production was used. According to the pilot DH inventory, new boiler house was set in modular container and heat is produced in wood pellet boiler with automatic silo and storage area. The old boiler house did not have silo and heat was produced in firewood boiler.

Ecoinvent 3 database does not have DH pipeline as an assembly and therefore DH network pipelines were included in LCA as materials and processes needed for production of DH network pipeline of specific sizes, which were given in inventory of pilot DH. According to DH network pipeline manufacturer certificates, the pipeline consists of three parts: inner part is metal pipeline, middle part is insulation without channel and outer part is plastic cover. The weight of materials needed for pipeline can be calculated from volume and density of material. From the data available in inventory calculation of pipeline material weight was made according to Eq. (1). 


$$
V_{n}=\left(\pi \cdot R_{n}^{2}-\pi \cdot r_{n}^{2}\right) \cdot \rho_{n} \cdot l
$$

where

$V_{n} \quad$ Volume of pipeline material $n, \mathrm{~m}^{3}$;

$\pi \quad$ Ratio of the circumference of a circle to its diameter, mathematical constant;

$R_{n} \quad$ Outer radius of pipeline material $n, \mathrm{~m}$;

$r_{n} \quad$ Inner radius of pipeline material $n, \mathrm{~m}$;

$\rho_{n} \quad$ Density of pipeline material $n, \mathrm{~kg} / \mathrm{m}^{3}$;

$l \quad$ Length of pipeline, $\mathrm{m}$.

Pipeline assembly was included in LCA model as the sum of the material weights estimated according to Eq. 1. The example for data about the size of pipelines used for calculation of material weights from pilot DH inventory is shown in Table 3.

TABLE 3. EXAMPLE OF DH PIPELINE INVENTORY

\begin{tabular}{lllllll}
\hline Pipeline in new DH network inventory & Amount & Unit & \multicolumn{3}{c}{ Thickness of pipeline parts, mm } \\
\cline { 5 - 7 } & & & & Metal pipe & Insulation & PE cover \\
\hline Heating pipeline d76/D160 & 12 & $\mathrm{~m}$ & 5.5 & 40.0 & 4 \\
Heating pipeline d60/D140 & 54 & $\mathrm{~m}$ & 5 & 37.5 & 4 \\
Heating pipeline d48/D125 & 222 & $\mathrm{~m}$ & 4 & 36.0 & 4 \\
Heating pipeline d33/D110 & 4 & $\mathrm{~m}$ & 4 & 36.0 & 4 \\
Corner d76/160 $\left(\alpha=90^{\circ}\right) 1.00 \cdot 1.00 \mathrm{~m}$ & 2 & $\mathrm{p}$ & 5.5 & 40.0 & 4 \\
Corner d48/125 $\left(\alpha=90^{\circ}\right) 0.50 \cdot 0.50 \mathrm{~m}$ & 4 & $\mathrm{p}$ & 5 & 37.5 & 4 \\
Corner d33/110 $\left(\alpha=90^{\circ}\right) 0.50 \cdot 0.50 \mathrm{~m}$ & 2 & $\mathrm{p}$ & 4 & 36.0 & 4 \\
Corner d60/140 $\left(\alpha=90^{\circ}\right) 0.50 \cdot 0.50 \mathrm{~m}$ & 6 & $\mathrm{p}$ & 4 & 36.0 & 4 \\
\hline
\end{tabular}

Note: Units measured in meters (m) and pieces (p).

Following assumption for density of materials in pipeline were adopted: inner pipe steel density $8050 \mathrm{~kg} / \mathrm{m}^{3}$, PUR insulation density $70 \mathrm{~kg} / \mathrm{m}^{3}$, PE cover density $970 \mathrm{~kg} / \mathrm{m}^{3}$. For pipeline connection parts is was assumed that insulation is $25 \%$ and cover is $75 \%$ of connection total weight.

The data characterizing former DH was obtained for reference year 2017 in terms of total heat production and electricity consumption of former boiler house and DH network pumps. For former boiler house and new boiler house fuel appropriate boiler of $300 \mathrm{~kW}$ was included the model. The data included in scenario energy flow is shown in Table 4.

TABLE 4. ENERGy Flows IN DEFINED SCENARIOS

\begin{tabular}{lllll}
\hline Scenario & Total heated area & Produced heat & Consumed fuel & Consumed electricity \\
\hline Scenario 1 & $4067 \mathrm{~m}^{2}$ & $524.76 \mathrm{MWh}$ & $119.74 \mathrm{t}$ of wood pellets & $4.58 \mathrm{MWh}$ from grid \\
Scenario 2 & $4067 \mathrm{~m}^{2}$ & $524.76 \mathrm{MWh}$ & $119.74 \mathrm{t}$ of wood pellets & $2.46 \mathrm{MWh}$ from grid and \\
& & & & $2.12 \mathrm{MWh}$ from solar PV \\
Scenario 3 & $4067 \mathrm{~m}^{2}$ & $532.57 \mathrm{MWh}$ & $121.52 \mathrm{t}$ of wood pellets & $4.58 \mathrm{MWh}$ from grid \\
Scenario 4 & $4467 \mathrm{~m}^{2}$ & $984.00 \mathrm{MWh}$ & $404.09 \mathrm{t}$ of firewood & $44.39 \mathrm{MWh}$ from grid \\
\hline
\end{tabular}


Wood pellet consumption was estimated for equivalent operation conditions as in case of former DH for reference year 2017, considering the parameters of new DH in terms of total heated area and increase in efficiency due to new boiler installation and pipeline insulation.

The produced heat consists of the consumed heat and the heat losses. The consumed amount of heat for each scenario is calculated as a sum of consumption for all connected building before and after reconstruction. Heat loss has been determined according the methodology described in [42] by taking into account the particular heating network parameters and temperature levels. Heat consumption and heat loss has been determined for the average climate conditions in Gulbene (heating season 209 days, average heating season temperature $-1.4{ }^{\circ} \mathrm{C}$ ). The fuel consumption is obtained according to Eq. (2):

$$
B=\frac{Q_{i}}{Q_{z, i}^{d} \cdot \eta_{i}},
$$

where

$B \quad$ Fuel consumption for fuel $i$, tonnes per year;

$Q_{i} \quad$ Produced heat, MWh per year;

$Q_{z}{ }^{d} \quad$ Lowest calorific value for fuel $i, \mathrm{MWh} /$ tonnes per year;

$\eta_{i} \quad$ Boiler efficiency for fuel $i$.

Efficiency of new boiler was considered as $91.3 \%$ according for nominal load and lowest calorific value for pellets $4.8 \mathrm{MWh} /$ tones according to manufacturer's certificate.

The power consumption data of new and old boiler house has been used to determine the specific power that is necessary to produce and transfer $1 \mathrm{MWh}$ of heat. This indicator has been applied for both high and low temperature regimes due to assumption that supply and return temperature difference will remain constant in both scenarios.

In scenario 2 electricity from solar panels is generated throughout the year, but since the consumption of DH during the summer is almost close to zero, the electricity is not used in this period. It is assumed that surplus electricity in summer is consumed for other needs than $\mathrm{DH}$, therefore is not assign to this scenario, while during winter solar PV generate s electricity according to solar PV area and monthly irradiation. This generated electricity considered to substitute part of the electricity coming from country mix.

\subsection{Impact Assessment}

The aim of this case study is to assess a wide range of environmental impacts of DH development scenarios. For this purpose, impact assessment was performed with SimaPro 9.0 software. Software allows to use number of impact assessment methods can be applied to calculate results depending on the purpose of the project. Standard procedure according to ISO standards include characterization, damage assessment, normalization, weighting and addition steps, if needed.

For this study, the IMPACT 2002+ version 2.14 method that considers factors as human toxicity, aquatic and terrestrial ecotoxicity, and also characterization factors adapted from methods like Eco-indicator 99, CML 2001, Intergovernmental Panel on Climate Change and the Cumulative Energy Demand. This method includes 14 midpoint categories: human toxicity, respiratory effects, ionizing radiation, ozone layer depletion, photochemical oxidation, aquatic ecotoxicity, terrestrial ecotoxicity, aquatic acidification, aquatic eutrophication, terrestrial acid/nutrients, land occupation, global warming, non-renewable 
energy, and mineral extraction. The scores of these 14 midpoint categories is assign to impact respective endpoint category:

1) Damage to human health is expressed as Disability Adjusted Life Years (DALYs);

2) Damage to Ecosystem Quality is expressed as the loss of species over a certain area (PDF);

3) Damage to Resources, expressed as the surplus energy needed for future extractions of minerals and fossil fuels (MJ);

4) Damage to climate change, expressed in terms of overall $\mathrm{CO}_{2}$ equivalent, excluding biogenic carbon impact.

The endpoint scores are normalized to one scale and expressed as the number of equivalent persons affected during one year per unit of emission. Each damage category is given weight of one. Single score is estimated as cumulative value of these weighted scores of categories. The high score shows high environmental impact. The selection of the method was mainly due to have climate change as standing alone end point category. More detailed description of the method is presented literature [43].

\section{Results}

The total environmental impact and damage category score of each scenario is presented in Fig. 1. Score is presented as an Eco-indicator points, kPt, in relation to the Functional unit.

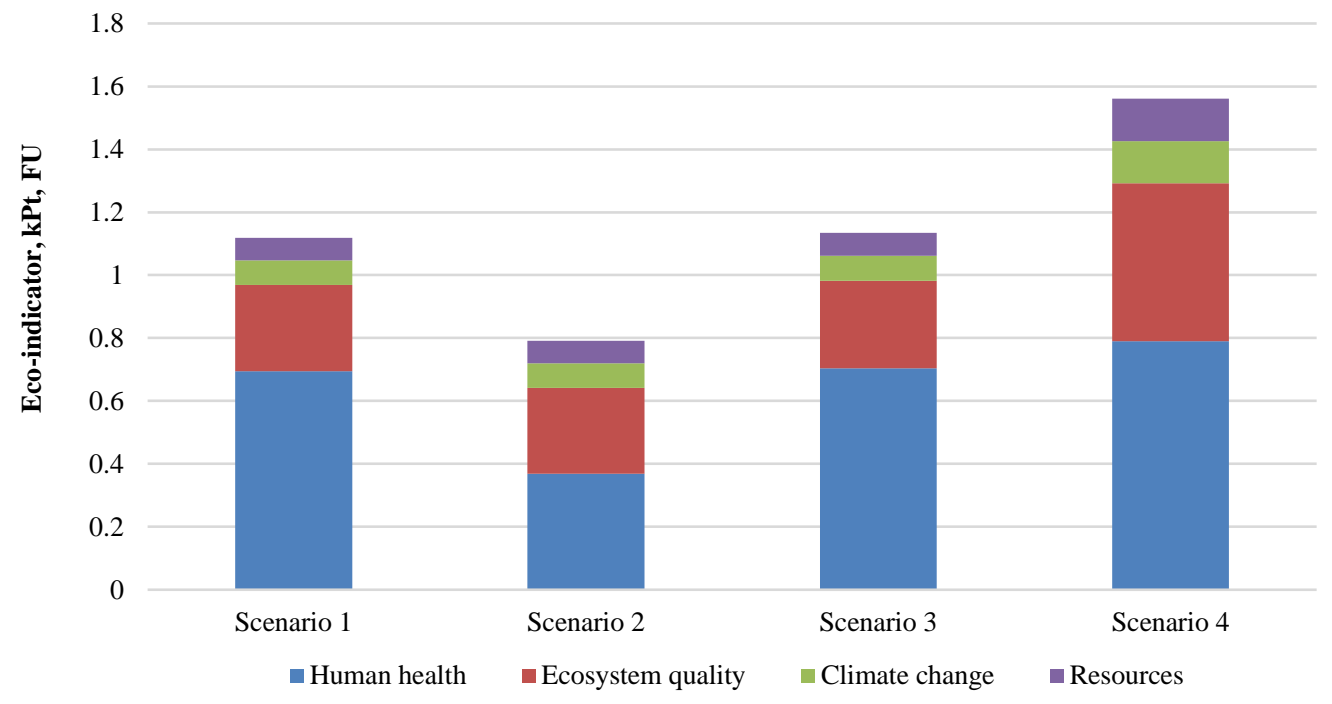

Fig. 1. Impact assessment score for scenarios.

Scenario 2 has the lowest impact on environment for all the categories: $0.791 \mathrm{kPt}$; while the scenario 4 has the most impact on environment for all the categories: $1.561 \mathrm{kPt}$. Scenarios 1 and 3 have close single score result of $1.119 \mathrm{kPt}$ and $1.134 \mathrm{Pt}$, respectively. This means that there that for temperature decrease from $90 / 60{ }^{\circ} \mathrm{C}$ to $60 / 35^{\circ} \mathrm{C}$ in pilot $\mathrm{DH}$ environmental impact decrease is small. When implementing solar PV in pilot $\mathrm{DH}$ the environmental impact decrease is more significant.

Overall, the highest impact in all scenarios is observed for human health category, followed by ecosystem quality category. Scores for climate change category are slightly higher than for resource category in all scenarios. 
Fig. 2 shows contribution to single score per part of DH in every scenario. The highest contribution to score in all scenarios is from energy flows. For scenario 2 the contribution to score is lower because of solar PV implementation. However, solar PV installation is accounted in boiler house part for scenario 2, so the for this scenario is higher for boiler house part than other two new LTDH and DH in scenario 1 and 3. Scenario 4 for old DH stands out with highest score in all categories with exception of nodes. Nodes have the lowest impact compared to other parts of DH. Model considered the same impact for nodes in all scenarios.

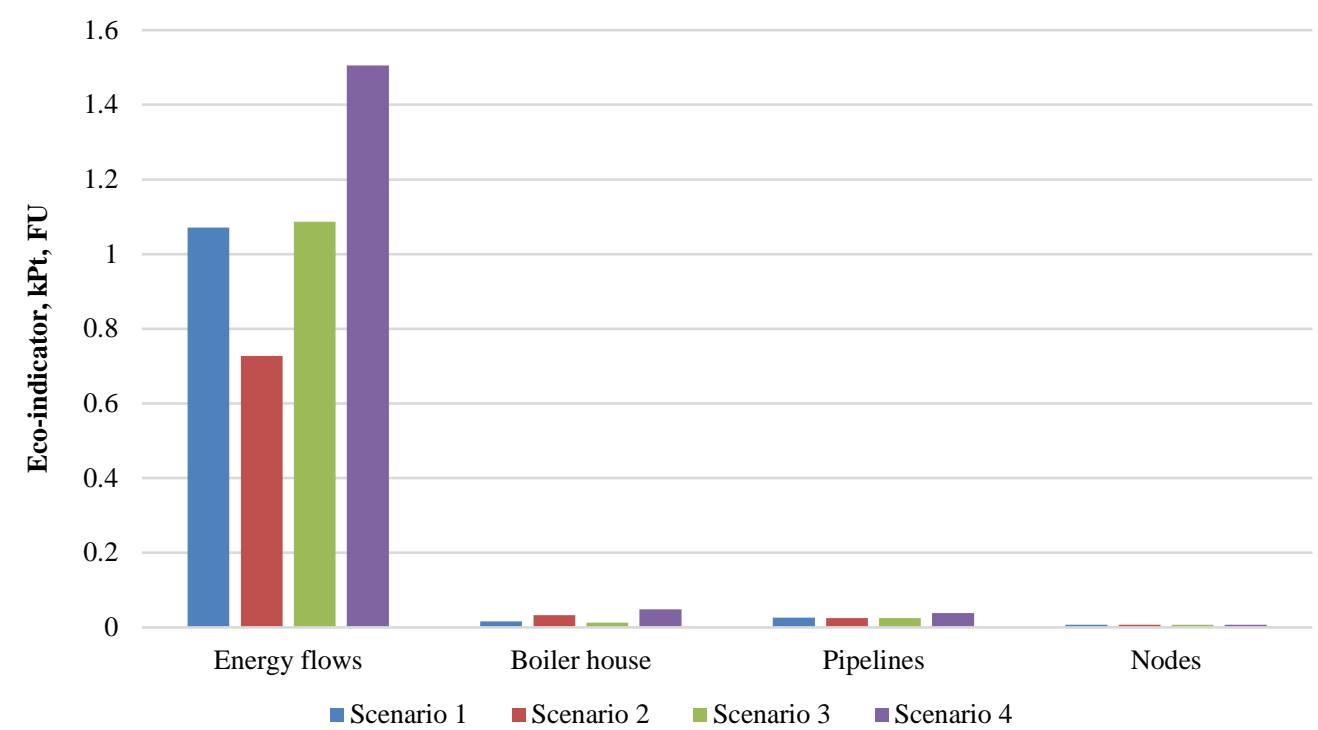

Fig. 2. Impact assessment score per part of DH.

Table 5 shows the process contribution to a total score of scenarios per part of DH for presented scenarios. According to this table, the energy flows account from $93 \%$ to $96 \%$ of scenario score. By studying the results from perspective of contribution processes within SimaPro software, heat production with ash treatment was found to be main contributors within energy flows of DH.

TABLE 5. CONTRIBUTION TO TOTAL SCORE OF SCENARIOS PER PART OF DH

\begin{tabular}{lllll}
\hline Part of DH & Scenario 1 & Scenario 2 & Scenario 3 & Scenario 4 \\
\hline Energy flows & $96 \%$ & $93 \%$ & $96 \%$ & $94 \%$ \\
Boiler house & $1 \%$ & $3 \%$ & $1 \%$ & $3 \%$ \\
Pipelines & $2 \%$ & $3 \%$ & $2 \%$ & $2 \%$ \\
Nodes & $1 \%$ & $1 \%$ & $1 \%$ & $0.5 \%$ \\
\hline
\end{tabular}

\section{Conclusions}

LCA contributes to raising awareness of environmental impacts that can be caused by DH systems. It provides an insight on damages in several categories that are not captured by other available methods. It is thus an essential tool to cover the knowledge gaps of stakeholders involved in infrastructure planning and reconstruction. 
The aim of this study was to assess environmental impacts of different renewing/modernizing scenarios of an existing DH system and a LTDH system, which also includes the application of solar PV. The study utilized the LCA methodology in SimaPro software. Data was obtained from Ecoinvent 3 database, which includes the latest data about country electricity mix. Damage assessment was made according to the IMPACT 2002+ method.

The results showed that there is major improvement in environmental performance of DH from modernization of the boiler house. The scenario which implemented LTDH with supply and return temperatures of $60 / 35{ }^{\circ} \mathrm{C}$ and solar PV was found to be the best form environmental perspective among all the studied scenarios for DH modernization. The highest contribution to environmental impact in all scenarios was from energy flows during the operation phase of DH. Study showed that construction and maintenance of DH compared to operation has much lower impact on environment.

One of the important finding of this study is that implementation of LTDH alone does not show significant improvement in environmental performance of DH heating. However, the study did not include sensitivity analysis of results.

In all scenarios DH operation in terms of heat production and ash treatment showed the highest contribution to environmental impact. In the future, to deal with this issue, not just lowering temperature of $\mathrm{DH}$, but also implementation of as solar thermal collectors and other low temperature sources such as heat pumps and excess industrial heat should be considered when designing new LTDH. This would change the required capacity of boiler house and thus the amount of heat produced and ashes created.

It is important to note that in the current state of system the energy efficiency was not applied in dwellings, thus there lies the potential to improve the overall environmental performance of scenarios with LTDH compared to modernized DH with supply and return temperatures of $90 / 60{ }^{\circ} \mathrm{C}$. Moreover, when modelling larger $\mathrm{DH}$, it would be important to consider the change of DH network electricity consumption due to change of supply and return temperatures.

The results of this study provide information DH development scenarios with low impact on environment and can be used by municipality and public authorities involved in planning process of infrastructure development.

\section{ACKNOWLEDGEMENT}

This work is supported by the European Commission through the EU INTERREG Baltic Sea Region Project No. R063 “Low Temperature District Heating for the Baltic Sea Region” (LowTEMP).

\section{ANNEX}

\begin{tabular}{llll}
\hline Part of DH & Materials/Assemblies/Processes & Amount & Unit \\
\hline New boiler house & Steel, low-alloyed & 113.3 & $\mathrm{~kg}$ \\
& Steel, chromium steel 18/8 & 390.1 & $\mathrm{~kg}$ \\
& Concrete, sole plate and foundation & 4.2 & $\mathrm{~m}^{3}$ \\
& Sand & 14 & $\mathrm{~kg}$ \\
& Polyurethane, rigid foam & 21.5 & $\mathrm{~kg}$ \\
& Cast iron & 23 & $\mathrm{~kg}$ \\
& Brass & 0.4 & $\mathrm{~kg}$ \\
& Stone wool & 1040 & $\mathrm{~kg}$ \\
& Flat glass, coated & 4 & $\mathrm{~kg}$ \\
\hline
\end{tabular}




\begin{tabular}{|c|c|c|c|}
\hline Part of DH & Materials/Assemblies/Processes & Amount & Unit \\
\hline & Alkyd paint, white, without solvent, in $60 \%$ solution state & 3.6 & $\mathrm{~kg}$ \\
\hline & Polyethylene, low density, granulate & 5 & $\mathrm{~kg}$ \\
\hline & Exhaust air outlet, steel/aluminium, $85 \cdot 365 \mathrm{~mm}$ & 3 & $\mathrm{p}$ \\
\hline & Ventilation duct, connection piece, steel, $100 \cdot 50 \mathrm{~mm}$ & 5 & $\mathrm{p}$ \\
\hline & Room-connecting overflow element, steel, approx. $40 \mathrm{~m}^{3} / \mathrm{h}$ & 1 & $\mathrm{p}$ \\
\hline & Exhaust air outlet, steel/aluminium, $85 \cdot 365 \mathrm{~mm}$ & 1 & $\mathrm{p}$ \\
\hline & Ventilation duct, steel, $100 \cdot 50 \mathrm{~mm}$ & 5 & $\mathrm{~m}$ \\
\hline & Ventilation duct, connection piece, steel, $100 \cdot 50 \mathrm{~mm}$ & 1 & $\mathrm{p}$ \\
\hline & Insulation spiral-seam duct, rockwool, DN $400.30 \mathrm{~mm}$ & 4.95 & $\mathrm{~m}$ \\
\hline & Intermodal shipping container & 1 & $\mathrm{p}$ \\
\hline & Furnace, pellets, with silo, $300 \mathrm{~kW}$ & 1 & $\mathrm{p}$ \\
\hline & Metal working, average for steel product manufacturing & 113.3 & $\mathrm{~kg}$ \\
\hline & Metal working, average for chromium steel product manufacturing & 390.1 & $\mathrm{~kg}$ \\
\hline & Metal working, average for metal product manufacturing & 23.4 & $\mathrm{~kg}$ \\
\hline & Extrusion, plastic pipes & 3.6 & $\mathrm{~kg}$ \\
\hline \multirow{19}{*}{$\begin{array}{l}\text { New DH pipeline } \\
\text { network }\end{array}$} & Chromium steel pipe & 10639.4 & $\mathrm{~kg}$ \\
\hline & Polyurethane, rigid foam & 816.8 & $\mathrm{~kg}$ \\
\hline & Polyethylene, low density, granulate & 2038.7 & $\mathrm{~kg}$ \\
\hline & Concrete block & 2901 & $\mathrm{~kg}$ \\
\hline & Sand & 323.5 & $\mathrm{~kg}$ \\
\hline & Cast iron & 283 & $\mathrm{~kg}$ \\
\hline & Copper & 15 & $\mathrm{~kg}$ \\
\hline & Pitch & 10 & $\mathrm{~kg}$ \\
\hline & Alkyd paint, white, without solvent, in $60 \%$ solution state & 7.2 & $\mathrm{~kg}$ \\
\hline & Gravel, crushed & 570.2 & $\mathrm{~kg}$ \\
\hline & Mastic asphalt & 6733.8 & $\mathrm{~kg}$ \\
\hline & Cable, three-conductor cable & 5 & $\mathrm{~m}$ \\
\hline & Concrete, sole plate and foundation & 0.2 & $\mathrm{~m}^{3}$ \\
\hline & Metal working, average for steel product manufacturing & 10639.4 & $\mathrm{~kg}$ \\
\hline & Extrusion, plastic pipes & 2038.7 & $\mathrm{~kg}$ \\
\hline & Metal working, average for metal product manufacturing & 283 & $\mathrm{~kg}$ \\
\hline & Metal working, average for copper product manufacturing & 15 & $\mathrm{~kg}$ \\
\hline & Welding, arc, steel & 6.4 & $\mathrm{~m}$ \\
\hline & Excavation, hydraulic digger & 515 & $\mathrm{~m}^{3}$ \\
\hline \multirow[t]{12}{*}{ DH nodes } & Steel, low-alloyed & 256.8 & $\mathrm{~kg}$ \\
\hline & Stone wool & 1.2 & $\mathrm{~kg}$ \\
\hline & Cast iron & 132 & $\mathrm{~kg}$ \\
\hline & Copper & 9 & $\mathrm{~kg}$ \\
\hline & Brass & 61.6 & $\mathrm{~kg}$ \\
\hline & Stone wool & 1805.1 & $\mathrm{~kg}$ \\
\hline & Alkyd paint, white, without water, in $60 \%$ solution state & 4.8 & $\mathrm{~kg}$ \\
\hline & Cable, ribbon cable, 20-pin, with plugs & 15 & $\mathrm{~kg}$ \\
\hline & Metal working, average for steel product manufacturing & 256.8 & $\mathrm{~kg}$ \\
\hline & Metal working, average for metal product manufacturing & 132 & $\mathrm{~kg}$ \\
\hline & Metal working, average for copper product manufacturing & 9 & $\mathrm{~kg}$ \\
\hline & Welding, arc, steel & 0.3 & $\mathrm{~m}$ \\
\hline \multirow[t]{7}{*}{ Solar PV plant } & Photovoltaic panel, multi-Si wafer & 54.99 & $\mathrm{~m}^{2}$ \\
\hline & Electronic component, active, unspecified & 25.41 & $\mathrm{~kg}$ \\
\hline & Inverter, $2.5 \mathrm{~kW}$ & 2 & $\mathrm{p}$ \\
\hline & Steel, unalloyed & 112.5 & $\mathrm{~kg}$ \\
\hline & Cable, three-conductor cable & 155 & $\mathrm{~m}$ \\
\hline & Electric connector, wire clamp & 4 & $\mathrm{~kg}$ \\
\hline & Photovoltaic plant, electric installation for $3 \mathrm{kWp}$ module & 3.025 & $\mathrm{p}$ \\
\hline Pumps and taps & Brass & 89.5 & $\mathrm{~kg}$ \\
\hline
\end{tabular}




\begin{tabular}{|c|c|c|c|}
\hline \multirow[t]{13}{*}{ Part of DH } & Materials/Assemblies/Processes & Amount & Unit \\
\hline & Steel, low-alloyed & 72 & $\mathrm{~kg}$ \\
\hline & Steel, chromium steel $18 / 8$ & 264.3 & $\mathrm{~kg}$ \\
\hline & Polyethylene, high density, granulate & 17.4 & $\mathrm{~kg}$ \\
\hline & Cast iron & 145 & $\mathrm{~kg}$ \\
\hline & Bronze & 20.6 & $\mathrm{~kg}$ \\
\hline & Flat glass, coated & 4 & $\mathrm{~kg}$ \\
\hline & Battery cell, Li-ion & 0.9 & $\mathrm{~kg}$ \\
\hline & Electronics, for control units & 12.1 & $\mathrm{~kg}$ \\
\hline & Metal working, average for steel product manufacturing & 105 & $\mathrm{~kg}$ \\
\hline & Metal working, average for chromium steel product manufacturing & 264.3 & $\mathrm{~kg}$ \\
\hline & Metal working, average for metal product manufacturing & 165.6 & $\mathrm{~kg}$ \\
\hline & Thermoforming & 17.4 & $\mathrm{~kg}$ \\
\hline \multirow{18}{*}{$\begin{array}{l}\text { Surface box and } \\
\text { heat meters }\end{array}$} & Cast iron & 12 & $\mathrm{~kg}$ \\
\hline & Copper & 0.8 & $\mathrm{~kg}$ \\
\hline & Steel, low-alloyed & 12 & $\mathrm{~kg}$ \\
\hline & Steel, chromium steel $18 / 8$ & 3.5 & $\mathrm{~kg}$ \\
\hline & Brass & 14.2 & $\mathrm{~kg}$ \\
\hline & Electronics, for control units & 23.3 & $\mathrm{~kg}$ \\
\hline & Battery cell, Li-ion & 1 & $\mathrm{~kg}$ \\
\hline & Cable, ribbon cable, 20-pin, with plugs & 15 & $\mathrm{~kg}$ \\
\hline & Cable, three-conductor cable & 5 & $\mathrm{~m}$ \\
\hline & Polyethylene, high density, granulate & 0.4 & $\mathrm{~kg}$ \\
\hline & Polyethylene, low density, granulate & 5 & $\mathrm{~kg}$ \\
\hline & Polyurethane, rigid foam & 1.2 & $\mathrm{~kg}$ \\
\hline & Stone wool & 1805.1 & $\mathrm{~kg}$ \\
\hline & Metal working, average for steel product manufacturing & 12 & $\mathrm{~kg}$ \\
\hline & Metal working, average for chromium steel product manufacturing & 3.5 & $\mathrm{~kg}$ \\
\hline & Metal working, average for metal product manufacturing & 27 & $\mathrm{~kg}$ \\
\hline & Metal working, average for copper product manufacturing & 0.8 & $\mathrm{~kg}$ \\
\hline & Injection moulding & 5 & $\mathrm{~kg}$ \\
\hline
\end{tabular}

\section{REFERENCES}

[1] Mazhar A. R., Liu S., Shukla A. A state of art review on the district heating systems. Renewable and Sustainable Energy Reviews 2018:96:420-439. doi:10.1016/j.rser.2018.08.005

[2] Thellufsen J. Z., Nielsen S., Lund H. Implementing cleaner heating solutions towards a future low-carbon scenario in Ireland. Journal of Cleaner Production 2019:214:377-388. doi:10.1016/j.jclepro.2018.12.303

[3] Nord N., Kristine E., Nielsen L., Kauko H. Challenges and potentials for low-temperature district heating implementation in Norway. Energy 2018:151:889-902. doi:10.1016/j.energy.2018.03.094

[4] Schmidt D. Low Temperature District Heating for Future Energy Systems. Energy Procedia 2018:149:595-604. doi:10.1016/j.egypro.2018.08.224

[5] Winterscheid C. Integration of solar thermal systems in existing district heating systems. Energy 2017:137:579-585 doi:10.1016/j.energy.2017.04.159

[6] Connolly D., et al. Heat roadmap Europe: Combining district heating with heat savings to decarbonise the EU energy system. Energy Policy 2014:65:475-489. doi:10.1016/j.enpol.2013.10.035

[7] Rämä M., Sipilä K. Transition to low temperature distribution in existing systems. Energy Procedia 2017:116:58-68. doi:10.1016/j.egypro.2017.05.055

[8] Li H., Wang S. J. Challenges in smart Low-temperature district heating development. Energy Procedia 2014:61:1472-1475. doi:10.1016/j.egypro.2014.12.150

[9] Imran M., Usman M., Im Y. H., Park B. S. The feasibility analysis for the concept of low temperature district heating network with cascade utilization of heat between networks. Energy Procedia 2017:116:4-12. doi:10.1016/j.egypro.2017.05.050

[10] Schuchardt K. Integration of decentralized thermal storages within district heating networks. Environmental and Climate Technologies 2016:18:5-16. doi:10.1515/rtuect-2016-0009 
[11] Gadd H., Werner S. Achieving low return temperatures from district heating substations. Applied Energy 2014:136:59-67. doi:10.1016/j.apenergy.2014.09.022

[12] Dorotić H., Pukšec T., Duić N. Multi-objective optimization of district heating and cooling systems for a one-year time horizon. Energy 2019:169:319-328. doi:10.1016/j.energy.2018.11.149

[13] Volkova A., et al. Small low-temperature district heating network development prospects. Energy 2019:178:714-722. doi:10.1016/j.energy.2019.04.083

[14] Kouhia M., Laukkanen T., Holmberg H., Ahtila P. Evaluation of design objectives in district heating system design. Energy 2019:167:369-378. doi:10.1016/j.energy.2018.10.170

[15] Olsthoorn D., Haghighat F., Mirzaei P. A. Integration of storage and renewable energy into district heating systems: A review of modelling and optimization. Solar Energy 2016:136:49-64. doi:10.1016/j.solener.2016.06.054

[16] Fachinger F., Drewnick F., Gieré R., Borrmann S. Communal biofuel burning for district heating: Emissions and immissions from medium-sized (0.4 and 1.5 MW) facilities. Atmospheric Environment 2017:181:177-185. doi:10.1016/j.atmosenv.2018.03.014

[17] Caputo P., Ferla G., Ferrari S. Evaluation of environmental and energy effects of biomass district heating by a wide survey based on operational conditions in Italy. Energy 2019:174:1210-1218. doi:10.1016/j.energy.2019.03.073

[18] Morosuk T., Tsatsaronis G. Advanced exergy-based methods used to understand and improve energy-conversion systems. Energy 2019:169:238-246. doi:10.1016/j.energy.2018.11.123

[19] Gong M., Werner S. Exergy analysis of network temperature levels in Swedish and Danish district heating systems. Renewable Energy 2015:84:106-113. doi:10.1016/j.renene.2015.06.001

[20] Baldvinsson I., Nakata T. A feasibility and performance assessment of a low temperature district heating system A North Japanese case study. Energy 2016:95:155-174. doi:10.1016/j.energy.2015.11.057

[21] Yazici H. Energy and exergy based evaluation of the renovated Afyon geothermal district heating system. Energy and Buildings 2016:127:794-804. doi:10.1016/j.enbuild.2016.06.036

[22] Laukkanen T. P., Kohl T., Järvinen M. P., Ahtila P. Primary exergy efficiency-effect of system efficiency environment to benefits of exergy savings. Energy and Buildings 2016:124:248-254. doi:10.1016/j.enbuild.2015.09.035

[23] Andrić I., et al. On the performance of district heating systems in urban environment: an emergy approach. Journal of Cleaner production 2017:142:109-120. doi:10.1016/j.jclepro.2016.05.124

[24] Raugei M., Rugani B., Benetto E., Ingwersen W. W. Integrating emergy into LCA: Potential added value and lingering obstacles. Ecological Modelling 214:271:4-9. doi:10.1016/j.ecolmodel.2012.11.025

[25] Coss S., Verda V., Le-Corre O. Multi-objective optimization of district heating network model and assessment of demand side measures using the load deviation index. Journal of Cleaner Production 2018:182:338-351. doi:10.1016/j.jclepro.2018.02.083

[26] Patterson M., McDonald G., Hardy D. Is there more in common than we think? Convergence of ecological footprinting, emergy analysis, life cycle assessment and other methods of environmental accounting. Ecological Modelling 2017:362:19-36. doi:10.1016/j.ecolmodel.2017.07.022

[27] Oliver-Solà J., Gabarrell X., Rieradevall J. Environmental impacts of the infrastructure for district heating in urban neighbourhoods. Energy Policy 2009:37(11):4711-4719. doi:10.1016/j.enpol.2009.06.025

[28] Nitkiewicz A., Sekret R. Comparison of LCA results of low temperature heat plant using electric heat pump, absorption heat pump and gas-fired boiler. Energy Conversion and Management 2014:87:647-652. doi:10.1016/j.enconman.2014.07.032

[29] Parajuli R., et al. Life Cycle Assessment of district heat production in a straw fired CHP plant. Biomass and Bioenergy 2014:68:115-134. doi:10.1016/j.biombioe.2014.06.005

[30] Ivner J., Broberg Viklund S. Effect of the use of industrial excess heat in district heating on greenhouse gas emissions: A systems perspective. Resources Conservavtion and Recycing 2015:100:81-87. doi:10.1016/j.resconrec.2015.04.010

[31] Sandvall A. F., Ahlgren E. O., Ekvall T. Low-energy buildings heat supply-Modelling of energy systems and carbon emissions impacts. Energy Policy 2017:111:371-382. doi:10.1016/j.enpol.2017.09.007

[32] Bartolozzi Irizzi., F., Frey M. Are district heating systems and renewable energy sources always an environmental win-win solution? A life cycle assessment case study in Tuscany, Italy. Renewable and Sustainable Energy Reviews 2017:80:408-420. doi:10.1016/j.rser.2017.05.231

[33] Havukainen J., Nguyen M. T., Väisänen S., Horttanainen M. Life cycle assessment of small-scale combined heat and power plant: Environmental impacts of different forest biofuels and replacing district heat produced from natural gas. Journal of Cleaner Production 2018:172:837-846. doi:10.1016/j.jclepro.2017.10.241

[34] Pericault Y., Kärrman E., Viklander M., Hedström A. Data supporting the life cycle impact assessment and cost evaluation of technical alternatives for providing water and heating services to a suburban development in Gällivare Sweden. Data in Brief 2018:21:1204-1208. doi:10.1016/j.dib.2018.10.058

[35] Pakere I., Romagnoli F., Blumberga D. Introduction of small-scale 4th generation district heating system. Methodology approach. Energy Procedia 2018:149:549-554. doi:10.1016/j.egypro.2018.08.219

[36] Møller Sneum D., Sandberg E., Koduvere H., Olsen O. J., Blumberga D. Policy incentives for flexible district heating in the Baltic countries. Utilities Policy 2018:51:61-72. doi:10.1016/j.jup.2018.02.001 
[37] Park B. S., Imran M., Hoon I. Y., Usman M. Thermo-economic optimization of secondary distribution network of low temperature district heating network under local conditions of South Korea. Applied Thermal Engineering 2017:126:117-133. doi:10.1016/j.applthermaleng.2017.07.080

[38] Flores J. F. C., Lacarrière B., Chiu J. N. W., Martin V. Assessing the techno-economic impact of low-temperature subnets in conventional district heating networks. Energy Procedia 2017:116:260-272. doi:10.1016/j.egypro.2017.05.073

[39] Kauko H., Kvalsvik K. H., Rohde D., Hafner A., Nord N. Dynamic modelling of local low-temperature heating grids: A case study for Norway. Energy 2017:139:289-297. doi:10.1016/j.energy.2017.07.086

[40] Balić D., Maljković D., Lončar D. Multi-criteria analysis of district heating system operation strategy. Energy Conversion Management 2017:144:414-428. doi:10.1016/i.enconman.2017.04.072

[41] Lauka D., Pakere I., Blumberga D. First solar power plant in Latvia. Analysis of operational data. Energy Procedia 2018:147:162-165. doi:10.1016/j.egypro.2018.07.049

[42] Ziemele J., Pakere I., Blumberga D. Development of District Heating System in Case of Decreased Heating Loads. Presented at the 27th International Conference on Efficiency, Cost, Optimization, Simulation and Environmental Impact of Energy Systems (ECOS 2014), Turku, Finland, 2014:2044-2055.

[43] Kittipongvises S. Assessment of environmental impacts of limestone quarrying operations in Thailand. Environmental and Climate Technologies 2017:20(1):67-83. doi:10.1515/rtuect-2017-0011 